\title{
Effect of freezing on electrical properties and quality of thawed chicken breast meat
}

\author{
Ran Wei ${ }^{1}$, Peng Wang ${ }^{1}$, Minyi Han ${ }^{1}$, Tianhao Chen ${ }^{1}$, Xinglian $\mathrm{Xu}^{1, *}$, and Guanghong Zhou ${ }^{1}$
}

* Corresponding Author: Xinglian Xu Tel: +86-25-84395939, Fax: +86-25-84395939,

E-mail: xlxus@njau.edu.cn

${ }^{1}$ Key Lab of Meat Processing and Quality Control, MOE, Synergetic Innovation Centre of Food Safety and Nutrition, Jiangsu Collaborative Innovation Centre of Meat Production and Processing, Key Laboratory of Animal Products Processing, MOA National Centre of Meat Quality and Safety Control, MOST, College of Food Science and Technology, Nanjing Agricultural University, Nanjing 21009, China

Submitted Jun 3, 2016; Revised Aug 9, 2016; Accepted Aug 14, 2016
Objective: The objective of this research was to study the electrical properties and quality of frozen-thawed chicken breast meat and to investigate the relationship between these parameters at different times of frozen storage.

Methods: Thawed samples of chicken breast muscles were evaluated after being kept in frozen storage at $-18^{\circ} \mathrm{C}$ for different periods of time $(1,2,3,4,5,6,7$, and 8 months).

Results: The results showed that water-holding capacity (WHC) and protein solubility decreased while thiobarbituric acid-reactive substances content increased with increasing storage time. The impedance module of samples decreased during 8-month frozen storage. Pearson correlation coefficients showed that the impedance change ratio ( $Q$ value) was significantly $(\mathrm{p}<0.05)$ related to $\mathrm{pH}$, color, WHC, lipid oxidation and protein solubility, indicating a good relationship between the electrical properties and qualities of frozen-thawed chicken breast meat.

Conclusion: Impedance measurement has a potential to assess the quality of frozen chicken meat combining with quality indices.

Keywords: Impedance; Electrical Properties; Frozen-thawed Chicken Meat; Quality

\section{INTRODUCTION}

Freezing is a commonly accepted method of food preservation to ensure the safety of meat products in the global meat export market [1]. The worldwide commercialization of meat calls for frozen meat which can be preserved for long periods of time with lower transportation cost and lower price compared with fresh meat [2].

Chicken meat, well-known for its high protein and low fat characteristics, is an important component in healthy diets [3]. The consumption of poultry meat has increased over decades and has reached high levels worldwide $[4,5]$. Due to the growth in consumer demand for safe poultry products, chicken meat quality assessment and control has become a necessity [6].

During frozen storage, there are series of physical and biochemical changes, such as water loss, color change, lipid and protein oxidation, which can influence the quality of frozen chicken meat [7]. Much research has been done on the biochemical changes in different meats during frozen storage [7-10], and the results indicate increases in moisture loss, protein denaturation, oxidation of lipids and protein, and changes in color, with the increasing of the freezing time.

Traditional methods based on physical and chemical measurements have been performed to evaluate the quality of frozen meat [11]. Recently some instrumental methods to assess the quality of frozen meat have been reported, including single cell gel electrophoresis assay, Raman spectroscopy, low field nuclear magnetic resonance, visible and near-infrared spectral, and cryoscanning electron microscopy [12-16]. Most of these measurements are accurate and visualized, reflecting the changes in frozen meat tissue by analyzing deoxyribonucleic acid (DNA), structures 
of protein, water distribution or ice crystal size. However, these methods are destructive in nature, relatively expensive, timeconsuming and require skilled personnel.

One of the rapid, non-destructive and easy-to-use methods to analyze the quality of meat is bio-impedance [17]. Electrical impedance has been widely applied for the assessment of meat quality such as $\mathrm{pH}$, fat content, tenderness and freshness [17,18]. Freezing and thawing of meat disrupts the cell membranes and changes the internal structure of biological materials, and thus the impedance and electrical properties of meat [18]. In this sense, recent research has been conducted on the properties of fresh and frozen-thawed fish using electrical methods. Fuentes et al [19] reported that impedance measurement could be used to differentiate between fresh and frozen-thawed sea bream. The research of Vidaček et al [20] showed the possibility of using electrical measurements to assess the freezing history of fish for up to 4-month storage. The study of Kent et al [21] revealed time and temperature of storage of frozen cod were well predicted with the dielectric method. However, there is little information available on the electrical properties of long period frozen poultry meat. The structure and component contents of chicken meat tissue are different from fish tissue. Fish meat is tender and contains a higher percentage of water and tends to deteriorate more easily [22]. Therefore, it is necessary to study the electrical properties of chicken meat which has a longer frozen preservation storage period in order to apply bio-impedance to poultry meat quality control.

In the present study, the electrical properties and qualities of thawed chicken breast meat during different frozen storage were investigated. The relationship between the electrical impedance and meat quality using attributes such as water-holding capacity (WHC) and protein solubility of frozen chicken meat at different times of the storage were evaluated. By analyzing the electrical properties and quality results, we aimed to test the use of impedance measurement as a potential method to evaluate the quality for predicting freezing history of frozen-thawed chicken meat.

\section{MATERIALS AND METHODS}

\section{Materials}

Fresh breast meat without visible fat and skin tissue from whitefeather broiler chickens was purchased on the day of slaughter from a commercial meat processing plant (Yueda Group, Yancheng, Jiangsu, China). The meat was maintained at $4^{\circ} \mathrm{C}$ during transport to the laboratory. About $8 \mathrm{~h}$ after slaughter, samples were frozen in a plate freezer at $-40^{\circ} \mathrm{C}$. After fast freezing, samples were individually packed into moisture impermeable polyethylene bags and then stored $-18^{\circ} \mathrm{C}$ for up to 8 months. At 0,1 , $2,3,4,5,6,7$, or 8 months of storage at $-18^{\circ} \mathrm{C}$, samples were thawed at $4^{\circ} \mathrm{C}$ for $12 \mathrm{~h}$ and analyzed.

Measurement of $\mathrm{pH}$ and color
The $\mathrm{pH}$ of meat samples was measured using a digital $\mathrm{pH}$ meter (Thermo-Scientific Trion Series, Milan, Italy). The color of the breast muscles was assessed for lightness $\left(\mathrm{L}^{*}\right)$, redness $\left(\mathrm{a}^{*}\right)$ and yellowness $\left(b^{*}\right)$ with a Konica Minolta colorimeter (CR-400, Osaka, Japan) in three different sample locations.

\section{Water-holding capacity}

Thawing, cooking and pressing loss were determined according to the method as described by Li et al [23] with slight modifications. Thawing loss was calculated as a percentage of weight loss before and after thawing.

Two pieces $(4 \mathrm{~cm} \times 2 \mathrm{~cm} \times 2 \mathrm{~cm} 20 \pm 2 \mathrm{~g})$ cut from a thawed sample were individually cooked in a $75^{\circ} \mathrm{C}$ water bath until the central temperature reached $70^{\circ} \mathrm{C}$. The cooked samples were chilled to room temperature. Cooking loss was calculated as a percentage of weight loss before and after cooking.

Two $0.5 \mathrm{~cm}$ thick and $2.5 \mathrm{~cm}$ in diameter samples were removed from each thawed sample using a cylinder sampler (inner diameter, $2.50 \mathrm{~cm}$ ). Then samples were wrapped with 16 layers of tissue papers and pressed under a force of $350 \mathrm{~N}$ for $5 \mathrm{~min}$ using a compression machine (YYW-2, Nanjing Soil Instrument, Nanjing, China). Pressing loss was calculated as a percentage of weight loss before and after compression.

\section{Lipid oxidation}

The amounts of the thiobarbituric acid-reactive substances (TBARS) in minced breast meat samples were determined according to the method of Lund et al [24] and with slight modifications. A minced sample (5 g) was homogenized in 25 $\mathrm{mL}$ of $7.5 \%$ trichloracetic acid with $0.10 \%$ ethylenediaminetetraacetic acid using an Ultra Turrax for $30 \mathrm{~s}$ at 13,500 r/min and then filtered. Filtrate $(2 \mathrm{~mL})$ was then added to $2 \mathrm{~mL}$ of $0.02 \mathrm{M}$ thiobarbituric acid and incubated in a $95^{\circ} \mathrm{C}$ water bath for $30 \mathrm{~min}$ to develop color. After cooling at room temperature, the absorbance of the sample was measured at $532 \mathrm{~nm}$. The amounts of TBARS were expressed as mg of malondialdehyde per $g$ of meat.

\section{Protein solubility}

The solubility of the sarcoplasmic and total (sarcoplasmic+ myofibrillar) proteins were determined according to the method as described by Joo et al [25] with slight modifications. Sarcoplasmic proteins were extracted from $1 \mathrm{~g}$ muscle using $20 \mathrm{~mL}$ of ice-cold $0.025 \mathrm{M}$ potassium phosphate buffer ( $\mathrm{pH}$ 7.2). The samples were minced, homogenized, and then left on a shaker at $4^{\circ} \mathrm{C}$ overnight. Samples were centrifuged at $3,000 \mathrm{~g}$ for $15 \mathrm{~min}$ and protein concentration in the supernatants was determined by the Biuret method. Total protein was extracted from $1 \mathrm{~g}$ muscle using $20 \mathrm{~mL}$ of ice-cold $1.1 \mathrm{M}$ potassium iodide in 0.1 $\mathrm{M}$ phosphate buffer ( $\mathrm{pH}$ 7.2). The same procedures for homogenization, shaking, centrifugation, and protein determination were used as described above. Myofibrillar protein concentrations 
were obtained by difference between total and sarcoplasmic protein solubility. The protein solubility was expressed as $\mathrm{mg}$ of protein per $\mathrm{g}$ of meat.

\section{Impedance measurements}

The impedance of the samples was measured with a LCR electric bridge (AT2827-1, Applent Electricity Technology CO. LTD, Changzhou, China). The external part consisted of two rows of six copper needles (diameter: $2 \mathrm{~mm}$ ), which were twined by the copper wires. The distance between the rows was $3 \mathrm{~cm}$ while the distance was $1 \mathrm{~cm}$ between the pins in the same row (Figure 1). The modulus of the samples was measured at frequencies of $50 \mathrm{~Hz}$ and $200 \mathrm{kHz}$, while the voltage was set to $1 \mathrm{~V}$ as determined by others [26]. The impedance change ratio ( $Q$ value) was defined as $\mathrm{Q}=\left(\mathrm{Z}_{\mathrm{L}}-\mathrm{Z}_{\mathrm{H}}\right) \times 100 / \mathrm{Z}_{\mathrm{H}}$. $\mathrm{Z}_{\mathrm{L}}$ and $\mathrm{Z}_{\mathrm{H}}$ are the modulus of the samples at the frequency of $50 \mathrm{~Hz}$ and $200 \mathrm{kHz}$, respectively [27].

\section{Statistical analysis}

Statistical analyses were performed using SAS 9.12 (SAS Institute Inc., Cary, NC, USA; 2003) and all data were expressed as the means \pm standard error of the mean values. Twenty replicates were used for determination of physicochemical parameters, and each replicate was measured in triplicate. Data were analyzed using analysis of variance according to Duncan's multiple-range test at a significance level of $p<0.05$. To determine the correlation between the values of impedance measurements and other physiochemical parameters, the results were subjected to Pearson correlation coefficients using SAS.

\section{RESULTS AND DISCUSSION}

\section{Measurement of $\mathrm{pH}$, color, WHC, TBARS, and protein solubility}

The L* value of fresh chicken breast meat (50.93) was significantly higher than that of thawed samples during the 1 to 8 months storage $(\mathrm{p}<0.05)$, however, there were no differences in $L^{*}$ values of any samples frozen for 1 to 8 months (Table 1 ). The $\mathrm{a}^{*}$ value of the samples increased after the freezing treatment from 3.07 to 4.77 , reaching a peak on the 1st month of frozen storage. Then the value declined to 2.14 on the 8 th month of frozen storage with fluctuations. The $b^{*}$ value decreased from

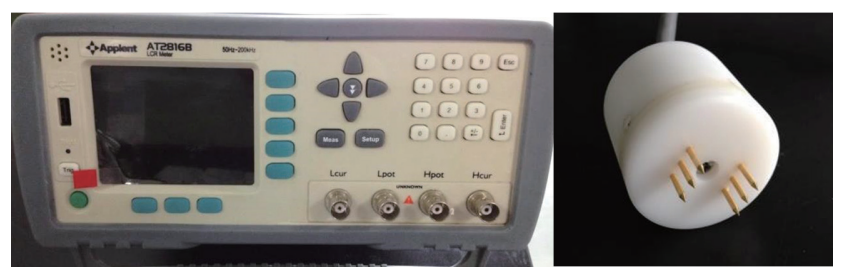

Figure 1. Photograph showing the impedance machine (left) and the probe (right) used in this work.
Table 1. Effects of time of frozen storage on $\mathrm{pH}$ and color $\left(L^{*}, a^{*}\right.$, and $\left.b^{*}\right)$ of chicken breast meat

\begin{tabular}{lcccc}
\hline $\begin{array}{c}\text { Storage time } \\
(\mathbf{m})\end{array}$ & $\mathbf{p H}^{1)}$ & $\mathbf{L}^{*}$ & $\mathbf{a}^{*}$ & $\mathbf{b}^{*}$ \\
\hline 0 & $6.09 \pm 0.10^{\mathrm{a}}$ & $50.93 \pm 2.64^{\mathrm{a}}$ & $3.07 \pm 0.81^{\mathrm{c}}$ & $8.23 \pm 1.14^{\mathrm{a}}$ \\
1 & $5.96 \pm 0.21^{\mathrm{b}}$ & $48.54 \pm 3.18^{\mathrm{b}}$ & $4.77 \pm 0.99^{\mathrm{a}}$ & $4.10 \pm 0.95^{\mathrm{cd}}$ \\
2 & $5.97 \pm 0.15^{\mathrm{b}}$ & $47.18 \pm 1.19^{\mathrm{b}}$ & $4.64 \pm 0.72^{\mathrm{a}}$ & $3.79 \pm 0.95^{\mathrm{d}}$ \\
3 & $5.99 \pm 0.26^{\mathrm{ab}}$ & $47.41 \pm 1.85^{\mathrm{b}}$ & $3.33 \pm 0.73^{\mathrm{bc}}$ & $3.80 \pm 0.98^{\mathrm{d}}$ \\
4 & $5.99 \pm 0.17^{\mathrm{ab}}$ & $47.22 \pm 1.87^{\mathrm{b}}$ & $3.74 \pm 0.78^{\mathrm{b}}$ & $3.72 \pm 0.85^{\mathrm{d}}$ \\
5 & $5.97 \pm 0.19^{\mathrm{b}}$ & $47.38 \pm 2.05^{\mathrm{b}}$ & $2.22 \pm 0.99^{\mathrm{d}}$ & $4.74 \pm 0.95^{\mathrm{c}}$ \\
6 & $5.95 \pm 0.10^{\mathrm{b}}$ & $48.02 \pm 1.53^{\mathrm{b}}$ & $4.47 \pm 1.06^{\mathrm{a}}$ & $6.59 \pm 2.09^{\mathrm{b}}$ \\
7 & $5.94 \pm 0.12^{\mathrm{b}}$ & $47.94 \pm 2.16^{\mathrm{b}}$ & $1.91 \pm 0.81^{\mathrm{d}}$ & $8.81 \pm 1.47^{\mathrm{a}}$ \\
8 & $5.99 \pm 0.11^{\mathrm{ab}}$ & $47.05 \pm 2.71^{\mathrm{b}}$ & $2.14 \pm 0.82^{\mathrm{d}}$ & $9.46 \pm 2.04^{\mathrm{a}}$ \\
\hline
\end{tabular}

$L^{*}$, lightness; $a^{*}$, redness; $b *$, yellowness; $S E$, standard error.

${ }^{1)}$ Values for $\mathrm{pH}$ and color are means $\pm \mathrm{SE}, \mathrm{n}=20$.

Different superscript letters $(a-d)$ in the column show significant difference $(p<0.05)$ between the different frozen time groups.

8.23 to 3.72 during 0 to 4 month frozen storage, followed by a rise to 9.46 by 8 months of storage. The decreasing of $L^{*}$ value could be caused by a reduction of water retention which leads to a lower surface light reflectivity [28]. The accumulation of metmyoglobin (MetMb) at the surface of meat during storage contributes significantly to its discoloration [29], which could explain the changes in $a^{*}$ value. The increasing lipid oxidation and the formation of MetMb are the main factors leading to the changes in $b^{*}$ value as well [30].

The $\mathrm{pH}$ of the fresh chicken meat was 6.09 , which was significantly higher than that when thawed $(\mathrm{p}<0.05)$ (Table 1$)$. This value dropped to 5.96 for samples frozen for 1 month, and it remained no higher than 5.99 among groups of different frozen storage durations. Previous studies have shown that freezing with subsequent exudate release and the loss of water from the meat may cause an increase in the concentration of the solutes, resulting in a decrease in the $\mathrm{pH}$ of thawed meat [1].

Cooking losses and pressing losses showed lower values for fresh meat (15.77\% and $23.86 \%$ respectively) and higher values for frozen-thawed meat rising to $20.89 \%$ and $35.06 \%$ respectively with fluctuations after 8 months of freezing (Table 2). Thawing losses grew from $2.53 \%$ to $4.27 \%$ with the increasing time up to 6 months of frozen storage, followed by a slight decline and ended up by $3.93 \%$. These results indicated that WHC of frozen-thawed chicken meat tended to decrease gradually (increased thawing cooking and pressing loss). This is in accordance with the results of a study on thawed beef [9]. The rising cooking and pressing losses indicated an increase in protein denaturation with the attendant loss of ability to hold water. The growing thawing loss probably resulted from the rupture of cell structures and tissues caused by ice crystal growth during the freezing process and time of storage [31].

There was a gradual rise from 0.093 to $0.125 \mathrm{mg} / \mathrm{kg}$ in the TBARS content of chicken breast meat during 0 to 5 months frozen storage (Table 3). The content of TBARS witnessed a 
Table 2. Effects of time of frozen storage on WHC of chicken breast meat

\begin{tabular}{lccc}
\hline $\begin{array}{c}\text { Storage time } \\
(\mathbf{m})\end{array}$ & Thawing loss $(\%)^{1)}$ & Cooking loss $(\%)$ & Pressing loss $(\%)$ \\
\hline 0 & - & $15.77 \pm 1.92^{\mathrm{f}}$ & $23.86 \pm 1.84^{\mathrm{d}}$ \\
1 & $2.53 \pm 1.13^{\mathrm{c}}$ & $17.35 \pm 1.57^{\mathrm{de}}$ & $31.35 \pm 4.71^{\mathrm{c}}$ \\
2 & $2.61 \pm 1.52^{\mathrm{bc}}$ & $16.43 \pm 1.34^{\mathrm{ef}}$ & $34.36 \pm 2.91^{\mathrm{a}}$ \\
3 & $3.29 \pm 1.32^{\mathrm{abc}}$ & $17.85 \pm 1.52^{\mathrm{cd}}$ & $36.07 \pm 2.21^{\mathrm{ab}}$ \\
4 & $3.38 \pm 1.05^{\mathrm{abc}}$ & $22.17 \pm 2.53^{\mathrm{ab}}$ & $35.60 \pm 2.45^{\mathrm{a}}$ \\
5 & $3.37 \pm 2.23^{\mathrm{abc}}$ & $22.34 \pm 2.61^{\mathrm{a}}$ & $35.98 \pm 2.92^{\mathrm{a}}$ \\
6 & $4.27 \pm 1.37^{\mathrm{a}}$ & $19.06 \pm 1.91^{\mathrm{c}}$ & $34.58 \pm 2.31^{\mathrm{ab}}$ \\
7 & $3.70 \pm 1.62^{\mathrm{ab}}$ & $21.10 \pm 1.48^{\mathrm{ab}}$ & $33.04 \pm 3.13^{\mathrm{bc}}$ \\
8 & $3.93 \pm 1.99^{\mathrm{a}}$ & $20.89 \pm 2.23^{\mathrm{b}}$ & $35.06 \pm 3.90^{\mathrm{ab}}$ \\
\hline
\end{tabular}

WHC, water-holding capacity; SE, standard error.

1) Values for thawing, cooking and pressing losses are means $\pm S E, n=20$

Different superscript letters (a-f) in the column show significant difference $(p<0.05)$

between the different frozen time groups.

significant rise to $0.159 \mathrm{mg} / \mathrm{kg}$ on the 7 th months of storage $(\mathrm{p}<0.05)$, and continued increasing to $0.202 \mathrm{mg} / \mathrm{kg}$ by 8 months of the frozen period. Similar behaviors have been observed in other studies on chicken meat [7]. Lipid oxidation during storage is a critical factor that can affect sensory characteristics of meat [32]. The results of the TBARS content explained the sudden rise of $b^{*}$ value during 6 to 8 months frozen storage as well $[33,34]$.

With increasing freezing time, the solubility of total protein, sarcoplasmic protein and myofibrillar protein in thawed samples experienced a downward trend, with a slight increase on the 3rd month of storage (Table 3 ). The solubility of total protein and sarcoplasmic protein fell from 247.28 to $201.70 \mathrm{mg} / \mathrm{g}$ and from 99.77 to $77.06 \mathrm{mg} / \mathrm{g}$ respectively with slight rises by the end, while the solubility of myofibrillar protein dropped from 147.51 to $123.81 \mathrm{mg} / \mathrm{g}$ with a slight rise on the 7th month of storage. Farouk et al [9] and Niu et al [35] reported similar results in the study of quality of beef and chicken breast meat. The results indicated a denaturation of total protein, sarcoplasmic protein and myofibrillar protein during the frozen storage period, which could be caused by the formation of hydrogen, disulfide and salt bonds $[8,35]$.

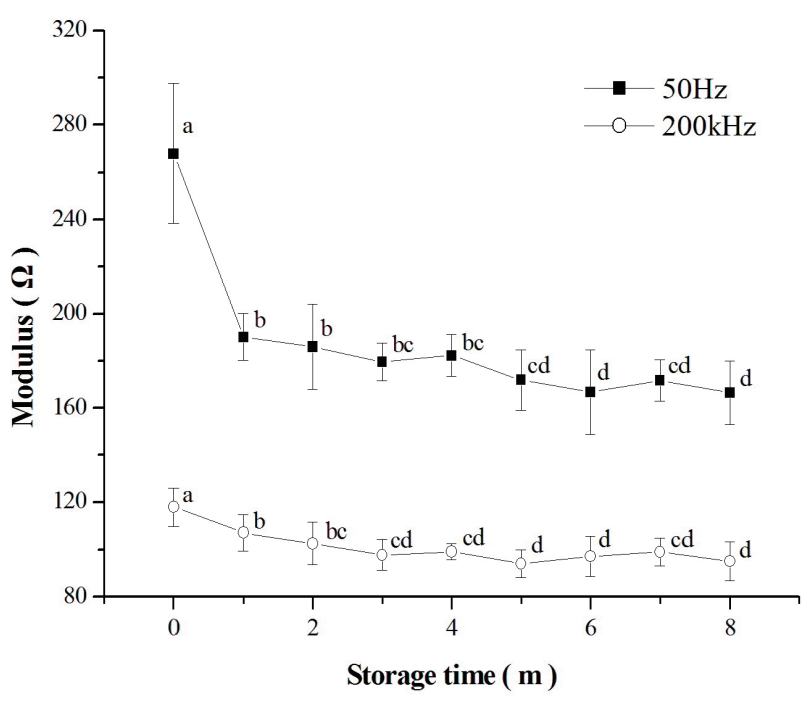

Figure 2. Impedance of chicken breast meat changes at the frequencies of $50 \mathrm{~Hz}$ and $200 \mathrm{kHz}$. Different superscript letters (a-d) in the column show significant difference $(p<0.05)$ between the different frozen time groups.

\section{Impedance measurements}

The impedance module of fresh chicken breast meat and thawed samples at 1, 2, 3, 4, 5, 6, 7, and 8 months of frozen storage are shown in Figure 2. The results showed that the impedance module of fresh meat (268.01 $\Omega$ and $117.93 \Omega$ respectively) was significantly higher than that of those thawed at frequencies of $50 \mathrm{~Hz}$ and $200 \mathrm{kHz}(\mathrm{p}<0.05)$. These findings are in accordance with those obtained by Fuentes et al [19] on fish muscle. With increasing time of the frozen storage, the modules of thawed meat at both frequencies decreased with fluctuations. The modules at the frequency of $50 \mathrm{~Hz}$ declined from $190.17 \Omega$ to $166.49 \Omega$, while the modules at the frequency of $200 \mathrm{kHz}$ reached the lowest values $(94.12 \Omega)$ on the 5 th month and ended up at 95.08 $\Omega$ by the 8 th month of storage. Previous studies on fish have showed that impedance of frozen-thawed grass carp decreased during a 10-day frozen storage [36]. The cell membrane acts as an insulator at low frequencies, behaving as a capacitor [17]. The membranes are intact in fresh meat, but in frozen-thawed

Table 3. Effects of time of frozen storage on TBARS and protein solubility of chicken breast meat

\begin{tabular}{lllll}
\hline Storage time $(\mathbf{m})$ & TBARS $(\mathbf{m g} / \mathbf{k g})^{1)}$ & TPS $(\mathbf{m g} / \mathbf{g})$ & SPS $(\mathbf{m g} / \mathbf{g})$ & MPS $(\mathbf{m g} / \mathbf{g})$ \\
\hline 0 & $0.093 \pm 0.01^{\mathrm{e}}$ & $247.28 \pm 22.44^{\mathrm{a}}$ & $99.77 \pm 8.93^{\mathrm{a}}$ & $147.51 \pm 17.24^{\mathrm{a}}$ \\
1 & $0.094 \pm 0.02^{\mathrm{e}}$ & $235.08 \pm 15.12^{\mathrm{b}}$ & $92.63 \pm 12.19^{\mathrm{b}}$ & $142.45 \pm 18.38^{\mathrm{ab}}$ \\
2 & $0.097 \pm 0.04^{\mathrm{e}}$ & $217.41 \pm 17.18^{\mathrm{c}}$ & $82.91 \pm 5.38^{\mathrm{c}}$ & $134.50 \pm 16.27^{b^{\mathrm{cc}}}$ \\
3 & $0.115 \pm 0.01^{\mathrm{de}}$ & $218.97 \pm 15.75^{\mathrm{c}}$ & $83.50 \pm 5.68^{\mathrm{c}}$ & $135.47 \pm 12.78^{\mathrm{b}}$ \\
4 & $0.124 \pm 0.01^{\mathrm{cd}}$ & $214.52 \pm 13.79^{\mathrm{c}}$ & $81.09 \pm 6.16^{\mathrm{cd}}$ & $133.43 \pm 13.62^{\text {bcd }}$ \\
5 & $0.125 \pm 0.02^{\mathrm{cd}}$ & $214.35 \pm 11.33^{\mathrm{c}}$ & $81.59 \pm 7.39^{\mathrm{cd}}$ & $132.76 \pm 14.69^{\mathrm{bcd}}$ \\
6 & $0.141 \pm 0.04^{\mathrm{bc}}$ & $203.45 \pm 16.57^{\mathrm{d}}$ & $79.90 \pm 6.81^{\mathrm{cd}}$ & $123.55 \pm 15.80^{\mathrm{d}}$ \\
8 & $0.159 \pm 0.03^{\mathrm{b}}$ & $201.70 \pm 16.74^{\mathrm{d}}$ & $77.06 \pm 5.00^{\mathrm{d}}$ & $124.67 \pm 14.73^{\text {cd }}$ \\
\hline
\end{tabular}

TBARS, thiobarbituric acid-reactive substances; TPS, total protein solubility; SPS, sarcoplasmic protein solubility; MPS, myofibrillar protein solubility; SE, standard error.

${ }^{1)}$ Values for TBARS, TPS, SPS and MPS are means \pm SE, $n=20$.

Different superscript letters $(a-e)$ in the column show significant difference $(p<0.05)$ between the different frozen time groups. 
samples cell membranes become destroyed [1]. The destruction of the cell membranes reduces the capacitive component of the biological tissues and increases the amount of free electrolytes in the tissue, increasing its conductivity and producing a decrease of the impedance module [19]. So the impedance module of fresh meat is much higher than in those thawed. However, the impedance of biological tissues changes much more slowly during the frozen storage [18]. The growth of ice crystals, denaturation of proteins, oxidation of lipids, and leakage of fluid from meat tissue during the frozen storage could contribute to the decrease of the impedance module.

The $\mathrm{Q}$ value of the fresh and frozen-thawed samples is presented in Table 4. The $Q$ value of fresh meat was $127.11 \%$, which was significantly higher than that of frozen-thawed $(\mathrm{p}<0.05)$. The $\mathrm{Q}$ value of frozen-thawed samples increased from $77.84 \%$ to $83.95 \%$ with the extension of frozen storage time, followed by a decrease to $71.54 \%$ on the 6 th month of storage. The value then rose to $75.44 \%$ by the end of frozen storage period. Biological tissues are composed of cells that are surrounded by extracellular fluid. Low-frequency current bypasses the cells through the extracellular fluid, while high-frequency current flows through the plasma membranes capacitance and cells $[37,38]$. After a frozen-thawed process, the muscle cells are damaged, which concentrate the solutes in meat. The cell cytoplasm as well as the surrounding extracellular fluid change in electrical conductivity [39]. This change in conductivity would lead to lower $\mathrm{Q}$ values in thawed chicken meat samples. It can be seen in Figure 2 that the modules of frozen-thawed samples decreased more rapidly after 4 months of storage at the frequency of $50 \mathrm{~Hz}$, while at the frequency of $200 \mathrm{kHz}$ the change was slower after 3 months of storage. Therefore, as time of frozen storage increased, the $\mathrm{Q}$ values increased up to the 4 th month of storage and declined by the end of the period. These impedance results could be explained by the theory mentioned above.

Pearson correlation coefficients were used to study the relationships between the quality indices and the electrical properties
Table 4. Effects of time of frozen storage on Q values of chicken breast meat

\begin{tabular}{|c|c|}
\hline Storage time $(\mathrm{m})$ & Q value 1$)(\%)$ \\
\hline 0 & $127.11 \pm 18.63^{\mathrm{a}}$ \\
\hline 1 & $77.84 \pm 7.63^{\mathrm{bcd}}$ \\
\hline 2 & $81.10 \pm 7.05^{b c}$ \\
\hline 3 & $83.93 \pm 7.84^{b}$ \\
\hline 4 & $83.95 \pm 10.35^{b}$ \\
\hline 5 & $82.63 \pm 8.53^{b}$ \\
\hline 6 & $71.54 \pm 11.31^{d}$ \\
\hline 7 & $73.31 \pm 6.66^{d}$ \\
\hline 8 & $75.44 \pm 9.98^{\mathrm{cd}}$ \\
\hline
\end{tabular}

of frozen-thawed chicken breast meat. The correlations between $\mathrm{pH}$, color, WHC, TBARS, protein solubility and the $\mathrm{Q}$ value are shown in Table 5. The color of frozen-thawed samples was significantly $(\mathrm{p}<0.05)$ related to WHC, TBARS, and protein solubility, confirming that the reduction of water retention and the increasing oxidation affected color change of frozen chicken meat. Protein solubility was significantly $(\mathrm{p}<0.001)$ correlated with TBARS, which indicated that there were interactions between protein denaturation and lipid oxidation during frozen storage. The $\mathrm{Q}$ value was not significantly related to $\mathrm{a}^{*}$ value and $b^{*}$ value $(p>0.05)$. The $\mathrm{pH}, \mathrm{L}^{*}$ value and protein solubility all had positive correlations with $\mathrm{Q}$ value, while other characteristics had negative correlations. The $\mathrm{Q}$ value was significantly $(p<0.001)$ related to $\mathrm{L}^{*}$ value, WHC, total protein and sarcoplasmic protein solubility, showing that the distribution of cellular liquid in meat tissues and denaturation of proteins affected the electrical properties of frozen-thawed chicken meat. Significant relationships between the $\mathrm{Q}$ value and other quality indicators $(\mathrm{p}<0.01)$ demonstrated that lipid oxidation and $\mathrm{pH}$ which were closely linked to the concentration of the solutes led to changes in electrical properties. The results showed that

Table 5. Pearson correlation coefficients between measured variables of chicken breast meat

\begin{tabular}{|c|c|c|c|c|c|c|c|c|c|c|c|}
\hline Variables & $\mathrm{pH}$ & $L^{*}$ & $a^{*}$ & $b^{*}$ & $\mathrm{CL}$ & PL & TBARS & TPS & SPS & MPS & $Q$ value \\
\hline $\mathrm{pH}$ & 1 & 0.002 & -0.017 & 0.039 & -0.119 & $-0.152^{*}$ & -0.035 & 0.116 & $0.163^{*}$ & 0.050 & 0.231 ** \\
\hline$L^{*}$ & & 1 & -0.049 & $0.221 * *$ & $-0.162^{*}$ & $-0.308^{* * *}$ & $-0.201^{* *}$ & $0.266^{* * *}$ & $0.233^{* *}$ & $0.198^{* *}$ & $0.263^{* * *}$ \\
\hline$a^{*}$ & & & 1 & $-0.385^{* * *}$ & $-0.280^{* * *}$ & -0.074 & $-0.294^{* * *}$ & $0.183^{*}$ & $0.182^{*}$ & 0.124 & -0.069 \\
\hline$b^{*}$ & & & & 1 & -0.101 & $-0.245^{* * *}$ & $0.401^{* * *}$ & -0.096 & -0.074 & -0.078 & 0.118 \\
\hline $\mathrm{CL}$ & & & & & 1 & $0.422^{* * *}$ & $0.365^{* * *}$ & $-0.306^{* * *}$ & $-0.333^{* * *}$ & $-0.191^{*}$ & $-0.373^{* * *}$ \\
\hline PL & & & & & & 1 & $0.233^{* *}$ & $-0.421^{* * *}$ & $-0.497^{* * *}$ & $-0.240^{* *}$ & $-0.562^{* * *}$ \\
\hline TBARS & & & & & & & 1 & $-0.420 * * *$ & $-0.377^{* * *}$ & $-0.308^{* * *}$ & $-0.273^{* *}$ \\
\hline TPS & & & & & & & & 1 & $0.638^{* * *}$ & $0.890^{* * *}$ & $0.453^{* * *}$ \\
\hline SPS & & & & & & & & & 1 & $0.217^{* *}$ & $0.496^{* * *}$ \\
\hline MPS & & & & & & & & & & 1 & $0.280^{* *}$ \\
\hline$Q$ value & & & & & & & & & & & 1 \\
\hline
\end{tabular}

L*, lightness; $a^{*}$, redness; b*, yellowness; CL, cooking loss; PL, pressing loss; TBARS, thiobarbituric acid-reactive substances; TPS, total protein solubility; SPS, sarcoplasmic protein solubility; MPS, myofibrillar protein solubility; $Q$ value, the impedance change ratio.

${ }^{*} p<0.05 ;{ }^{* *} p<0.01 ;{ }^{* *} p<0.001$. 
the deterioration in the quality of meat was closely linked to changes of the electrical properties.

Several studies have been performed relating the application of electrical measurements to estimating the quality of meat and fish. Kent et al [21] obtained a good relationship between sensory variables and dielectric parameters, which could predict time and temperature of storage of frozen cod. Vidaček et al [20] studied the impedance magnitude and phase of frozen-thawed fish and obtained promising results showing the possibility of a rapid and non-invasive assessment of the freezing history. Fuentes et al [19] detected changes in the degree of lipid oxidation, WHC and several textural parameters relating to the sensory quality of sea bream submitted to freezing-thawing processes, using the impedance spectroscopy technique. Therefore, electric conductivity can be applied to determine the component changes, thus predicting the freezing history of fish meat. Furthermore, Zhang et al [27] and Zhu et al [39] both found that it was practical to use Q values to evaluate the freshness of grass carp and bighead carp heads within a certain period of storage as a rapid, nondestructive method. In this study, good correlations were found between Q values and traditional quality indices as well as the degradation of protein for frozen-thawed chicken breast muscles. Although the structure and components of chicken meat are different from fish meat which has a shorter frozen preservation storage period [22], the results demonstrated that quality and electrical property of frozen-thawed chicken meat were closely linked, indicating the potential to predict the freezing history of chicken meat by impedance. To facilitate the application of impedance technology, further research should be conducted on predicting frozen storage time by using impedance value combined with quality indices for better quality control in poultry meat.

\section{CONCLUSION}

The good correlations between Q values and quality indices demonstrated that there was a good relationship between the electrical properties and qualities of thawed chicken breast meat during the period of frozen storage. The decreasing of WHC and protein solubility as well as the changes in color, $\mathrm{pH}$ and TBARS were closely related to the changes in impedance at different times of the frozen storage. By way of conclusion, the method of impedance measurement could be applied in the poultry industry to facilitate meat quality control. It is more reliable to assess the quality and the freezing history of frozen chicken meat using electrical properties together with quality attributes. These results are preliminary and further research should be carried out on the application of impedance measurement combining traditional quality indices in poultry meat quality control.

\section{CONFLICT OF INTEREST}

We certify that there is no conflict of interest with any financial organization regarding the material discussed in the manuscript.

\section{ACKNOWLEDGMENTS}

This work was supported by the Priority Academic Program Development of Jiangsu Higher Education Institutions (PAP), China Agriculture Research System (CARS-42), and National Science \& Technology Pillar Program during the Twelfth FiveYear Plan Period of China (2012BAD28B01).

\section{REFERENCES}

1.Leygonie C, Britz TJ, Hoffman LC. Impact of freezing and thawing on the quality of meat: Review. Meat Sci 2012;91:93-8.

2.Pietrasik Z, Janz JAM. Influence of freezing and thawing on the hydration characteristics, quality, and consumer acceptance of whole muscle beef injected with solutions of salt and phosphate. Meat Sci 2009;81:523-32.

3.Chumngoen W, Tan FJ. Relationships between descriptive sensory attributes and physicochemical analysis of broiler and Taiwan native chicken breast meat. Asian-Australas J Anim Sci 2015;28:1028-37.

4.Alexandrakis D, Downey G, Scannell AGM. Rapid non-destructive detection of spoilage of intact chicken breast muscle using nearinfrared and Fourier transform mid-infrared spectroscopy and multivariate statistics. Food Bioprocess Technol 2012;5:338-47.

5.Benli $\mathrm{H}$. Consumer attitudes toward storing and thawing chicken and effects of the common thawing practices on some quality characteristics of frozen chicken. Asian-Australas J Anim Sci 2016;29: $100-8$.

6.Carvalho RH, Soares AL, Grespan M, et al. The effects of the dark house system on growth, performance and meat quality of broiler chicken. Anim Sci J 2015;86:189-93.

7.Soyer A, Özalp B, Dalmış Ü, Bilgin V. Effects of freezing temperature and duration of frozen storage on lipid and protein oxidation in chicken meat. Food Chem 2010;120:1025-30.

8.Siddaiah D, Reddy GVS, Raju CV, Chandrasekhar TC. Changes in lipids, proteins and kamaboko forming ability of silver carp (Hypophthalmichthys molitrix) mince during frozen storage. Food Res Int 2001;34:47-53.

9.Farouk MM, Wieliczko KJ, Merts I. Ultra-fast freezing and low storage temperatures are not necessary to maintain the functional properties of manufacturing beef. Meat Sci 2004;66:171-9.

10. Muela E, Sañudo C, Campo MM, Medel I, Beltrán JA. Effect of freezing method and frozen storage duration on instrumental quality of lamb throughout display. Meat Sci 2010;84:662-9.

11. Damez JL, Clerjon S. Meat quality assessment using biophysical methods related to meat structure. Meat Sci 2008;80:132-49.

12. Park JH, Hyun CK, Jeong SK, et al. Use of the single cell gel electrophoresis assay (Comet assay) as a technique for monitoring low- 
temperature treated and irradiated muscle tissues. Int J Food Sci Technol 2000;35:555-61.

13. Herrero AM. Raman spectroscopy a promising technique for quality assessment of meat and fish: A review. Food Chem 2008;107:164251.

14. Bertram HC, Andersen RH, Andersen HJ. Development in myofibrillar water distribution of two pork qualities during 10-month freezer storage. Meat Sci 2007;75:128-33.

15. Liu Y, Chen YR. Two-dimensional correlation spectroscopy study of visible and near-infrared spectral variations of chicken meats in cold storage. Appl Spectrosc 2000;54:1458-70.

16. Ngapo TM, Babare IH, Reynolds J, Mawson RF. Freezing rate and frozen storage effects on the ultrastructure of samples of pork. Meat Sci 1999;53:159-68.

17. Pliquett U. Bioimpedance: a review for food processing. Food Eng Rev 2010;2:74-94

18. Damez JL, Clerjon S, Abouelkaram S, Lepetit J. Beef meat electrical impedance spectroscopy and anisotropy sensing for non-invasive early assessment of meat ageing. J Food Eng 2008;85:116-22.

19. Fuentes A, Masot R, Fernández-Segovia I, et al. Differentiation between fresh and frozen-thawed sea bream (Sparus aurata) using impedance spectroscopy techniques. Innov Food Sci Emerg Technol 2013;19:210-7.

20. Vidaček S, Janči T, Brdek Z, et al. Differencing sea bass (Dicentrarchus labrax) fillets frozen in different conditions by impedance measurements. Int J Food Sci Technol 2012;47:1757-64.

21. Kent M, Oehlenschlager J, Mierke-Klemeyer S, et al. Estimation of the quality of frozen cod using a new instrumental method. Eur Food Res Technol 2004;219:540-4.

22. Zhou G. Meat science and technology. Beijing, China: China Agriculture Press; 2008.

23. Li C, Liu D, Zhou G, et al. Meat quality and cooking attributes of thawed pork with different low field NMR T 21. Meat Sci 2012; 92:79-83.

24. Lund MN, Hviid MS, Claudi-Magnussen C, Skibsted LH. Effects of dietary soybean oil on lipid and protein oxidation in pork patties during chill storage. Meat Sci 2008;79:727-33.

25. Joo ST, Kauffman RG, Kim BC, Park GB. The relationship of sarcoplasmic and myofibrillar protein solubility to colour and waterholding capacity in porcine longissimus muscle. Meat Sci 1999;52: 291-7.

26. Krassen H, Pliquett U, Neumann E. Nonlinear current-voltage relationship of the plasma membrane of single $\mathrm{CHO}$ cells. Bioelectrochemistry
2007;70:71-7.

27. Zhang L, Shen H, Luo Y. A nondestructive method for estimating freshness of freshwater fish. Eur Food Res Technol 2011;232:97984.

28. Hughes JM, Oiseth SK, Purslow PP, Warner RD. A structural approach to understanding the interactions between colour, water-holding capacity and tenderness. Meat Sci 2014;98:520-32.

29. Bekhit AED, Cassidy L, Hurst RD, Farouk MM. Post-mortem metmyoglobin reduction in fresh venison. Meat Sci 2007;75:53-60.

30. Xiong YL. Protein oxidation and implications for muscle food quality. In: Decker E, Faustman C, Lopez-Bote CJ editors. Antioxidants in muscle foods: Nutritional strategies to improve quality. New York: John Wiley and Sons; 2000. pp. 85-111.

31. Songsaeng S, Sophanodora P, Kaewsrithong J, Ohshima T. Quality changes in oyster (Crassostrea belcheri) during frozen storage as affected by freezing and antioxidant. Food Chem 2010;123:286-90.

32. Muhlisin DTU, Lee JH, Choi JH, Lee SK. Antioxidant enzyme activity, iron content and lipid oxidation of raw and cooked meat of Korean native chickens and other poultry. Asian-Australas J Anim Sci 2016; 29:695-701.

33. Thanonkaew A, Benjakul S, Visessanguan W, Decker E. The effect of metal ions on lipid oxidation, colour and physicochemical properties of cuttlefish (Sepia pharaonis) subjected to multiple freezethaw cycles. Food Chem 2006;95:591-9.

34. Xia X, Kong B, Guo Y, Liu Q. Effect of freeze-thawing cycles on the quality properties and microstructure of pork muscle. Zhongguo Nongye Kexue 2009;42:982-8.

35. Niu L, Chen J, Huang M, Xu X, Zhou G. Effect of different frozen storage temperature and time on the eating quality of chicken breast meat. Nanjing Nongye Daxue Xuebao 2012;35:115-20

36. Zhang L, Shen H, Luo Y. Study on the electric conduction properties of fresh and frozen-thawed grass carp (Ctenopharyngodon idellus) and tilapia (Oreochromis niloticus). Int J Food Sci Technol 2010;45: 2560-4.

37. Arndt S, Seebach J, Psathaki K, Galla HJ, Wegener J. Bioelectrical impedance assay to monitor changes in cell shape during apoptosis. Biosens Bioelectron 2004;19:583-94.

38. Wegener J, Hakvoort A, Galla HJ. Barrier function of porcine choroid plexus epithelial cells is modulated by cAMP-dependent pathways in vitro. Brain Res 2000;853:115-24.

39. Zhu S, Luo Y, Hong H, Feng L, Shen H. Correlation between electrical conductivity of the gutted fish body and the quality of bighead carp (Aristichthys nobilis) heads stored at 0 and $3^{\circ} \mathrm{C}$. Food Bioprocess Technol 2013;6:3068-75. 